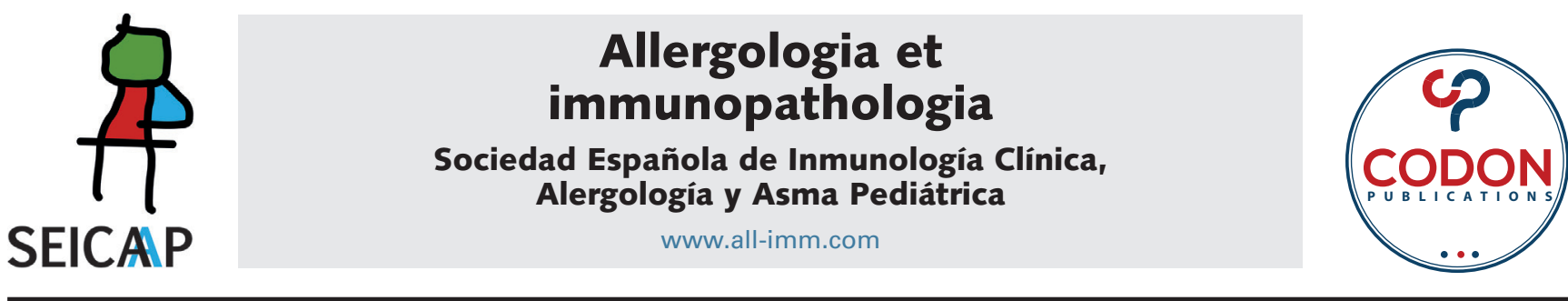

\title{
Mite avoidance decreased mite-specific IgE levels and ameliorated asthma symptoms in subjects who lived in temporary housing after natural disasters
}

\author{
Chiyako Oshikata ${ }^{\mathrm{a}, \mathrm{b}}$, Maiko Watanabe ${ }^{\mathrm{c}}$, Masatsugu Ishidad, Seiichi Kobayashid, \\ Kazuhiro Hashimoto ${ }^{\mathrm{e}}$, Naoki Kobayashif, Akiko Yamazaki ${ }^{\mathrm{g}}$, Rumi Konuma ${ }^{\mathrm{h}}$, \\ Takashi Shimada', Takeshi Kaneko ${ }^{\mathrm{b}}$, Yoichi Kamataj, Shinichi Kuriyama ${ }^{\mathrm{k}, \mathrm{l}}$, \\ Masaru Yanaid ${ }^{d}$ Naomi Tsurikisawa ${ }^{a, b *}$
}

\author{
${ }^{a}$ Department of Allergy and Respirology, Hiratsuka City Hospital, Hiratsuka, Japan \\ ${ }^{b}$ Department of Pulmonology, Yokohama City University Graduate School of Medicine, Kanazawa-ku, Japan \\ 'Division of Microbiology, National Institute of Health Sciences, Kawasaki-ku, Japan \\ ${ }^{d}$ Department of Respiratory Medicine, Japanese Red Cross Ishinomaki Hospital, Ishinomaki, Japan \\ eFCG Research Institute, Inc., Tokyo, Japan \\ fSchool of Life and Environmental Sciences, Azabu University, Sagamihara, Japan \\ ${ }^{8}$ Co-Department of Veterinary Medicine, Iwate University, Morioka, Japan \\ ${ }^{\text {h} T o k y o ~ M e t r o p o l i t a n ~ I n d u s t r i a l ~ T e c h n o l o g y ~ R e s e a r c h ~ I n s t i t u t e, ~ T o k y o, ~ J a p a n ~ 135-0064 ~}$ \\ iNichinichi Pharmaceutical Co. Ltd., Iga, Japan \\ ${ }^{j}$ Faculty of Life Science, Senri Kinran University, Suita, Japan \\ kTohoku University Graduate School of Medicine, Sendai, Japan \\ 'Tohoku University International Research Institute of Disaster Science, Sendai, Japan
}

Received 22 February 2021; Accepted 8 April 2021

Available online 1 July 2021

\section{KEYWORDS \\ adult asthma; allergen avoidance; Aspergillus; Dermatophagoides farinae; Great East Japan Earthquake in 2011.3.11; temporary housing; mite-specific lgE}

\begin{abstract}
Background: We previously reported an increased prevalence of asthma among patients who had lived in temporary housing after the 2011 Great East Japan Earthquake. We investigated the prognosis of asthma in former residents of temporary housing after allergen avoidance. Methods: Asthma was diagnosed in adults $\geq 15$ years from 2014 to 2019 who had lived in temporary housing in Ishinomaki City for at least 1 year. The disease prognosis after the intervention of allergen avoidance in cases that were followed for more than 3 years during the 6-year study period was analyzed. We measured the Dermatophagoides farinae -specific immunoglobulin E (IgE) levels in serum, and the amount of Dermatophagoides group 1 (Der 1) antigen on their futons or mattresses. We instructed residents in an allergen avoidance strategy that included 32 tasks, including using microfiber bedding covers.
\end{abstract}

*Corresponding author: Naomi Tsurikisawa, Department of Allergy and Respirology, Hiratuska City Hospital, 1-19-1 Minamihara, Hiratsuka, Kanagawa, Japan 254-0065. Email address: User831328@aol.com 
Results: Of the 202 examinees who were followed for at least 3 years during the 6-year study period, $72(35.6 \%)$ were asthmatic during at least one examination. Of these 72 asthmatics, 55(76.4\%) developed the disease after the earthquake, and more than half of the cases that we diagnosed at the examination were mild intermittent asthma. After the allergen-avoidance intervention, both the Der 1 level on the futons or mattresses of residents who were diagnosed with asthma but who were nonasthmatic at the final screening and their serum Der $f$-specific IgE levels significantly decreased $(P<0.01)$ at the final examination.

Conclusion: Antigen avoidance ameliorated mild asthma that was prevalent among residents of temporary housing after the earthquake.

(c) 2021 Codon Publications. Published by Codon Publications.

\section{Introduction}

The increased environmental humidity that follows natural disasters such as floods and tsunamis support the rapid multiplication of fungi and bacteria, resulting in infectious diseases and the exacerbation of asthma. ${ }^{1,2}$ Besides, evidence from epidemiologic studies and meta-analyses suggests that exposure to high levels of molds or dampness is associated with the development or exacerbation of asthma. ${ }^{3-5}$

After the 2011 Great East Japan Earthquake and the resulting tsunami, the prevalence of bronchial asthma and atopic dermatitis in children ${ }^{6,7}$ and the development and exacerbation of asthma in adults increased. ${ }^{8-10}$ Many of these patients were forced to live in temporary housing due to the flooding and water damage after the tsunami. ${ }^{10,11}$ The increased humidity within temporary housing is thought to promote the growth of fungi. ${ }^{12,13}$ Conversely, efforts to mitigate excess environmental humidity reduced fungal exposure and asthma exacerbation. ${ }^{14}$ Also, various species of mites, other well-known triggers of allergy and asthma, feed on fungi, especially Alternaria alternata, Cladosporium sphaerospermun, and Wallemia sebi,,$^{15}$ and levels of airborne fungi were increased inside houses in Fukushima after the earthquake. ${ }^{16}$

Mass screening for respiratory and allergic diseases revealed a $24 \%$ prevalence of asthma among adults (age $\geq$ 15 years) who currently or had lived previously in temporary housing in Ishinomaki ${ }^{10}$; this rate was higher than that previously reported in Japan. ${ }^{17,18}$ Besides, $45.9 \%$ of the asthmatic residents we screened developed asthma after moving into temporary housing, which likewise exacerbated the disease in $71.4 \%$ of the participants who had previously been diagnosed with asthma. ${ }^{10}$ Furthermore, we found that mite allergen was more important than Aspergillus fumigatus in the development or exacerbation of asthma. ${ }^{10}$

The prognosis of residents who developed asthma because of changes in their living quarters after the earthquake is unknown. Also, whether treatment strategies for avoiding mite or fungal antigens are effective for residents who developed asthma or experienced disease exacerbation due to postearthquake changes in their living environments are unclear.

In the current study, we performed group screening for respiratory and allergic diseases from 2014 to 2019 in adults (age $\geq 15$ years) who had lived in temporary housing for at least 1 year. We then analyzed those cases that were followed for at least 3 years during the 6-year screening period. During this follow-up, we measured mite-specific serum anti-immunoglobulin $\mathrm{E}$ (IgE) levels and the amounts of mite allergens on bedding, provided guidance on antigen avoidance, and evaluated whether environmental improvement interventions were effective for controlling asthma exacerbation in these former residents of temporary housing.

\section{Materials and methods}

\section{Study population}

We performed group screening for respiratory and allergic diseases from 2014 through 2019 in adults (age $\geq 15$ years) who currently were living in or had lived for at least 1 year in temporary housing in Ishinomaki, Miyagi Prefecture. ${ }^{10}$ The surveys covered the following complexes: (1) The Kaisei complex, the fourth and seventh Minamisakai complexes, the third and fourth Omori complexes, and the Jonai complex in 2014. (2) The Kaisei complex, Watanoha community center, and Koganehama community center in 2015. (3) The Kaisei complex, the Shinhebita Assembly Hall and surrounding rebuilt housing units, and the Japanese Red Cross Ishinomaki Hospital during 2016 through 2018. (4) The Shinhebita Assembly Hall and surrounding rebuilt housing units and the Japanese Red Cross Ishinomaki Hospital in 2019.

After 2016, most of the residents had moved out of temporary housing and lived in newly constructed homes, rental units, or reconstructed housing. Reconstructed public housing, also known as disaster public housing, is an economical option for people who lost their homes because of a natural disaster. They are more durable than shelters, temporary housing, and other housing types, from detached wood houses to reinforced apartments, that are available. However, the high demand for disaster public housing, many units have insufficient time to dry thoroughly before occupation.

We performed group screening for respiratory and allergic diseases in adults (age $\geq 15$ years) who currently were living or previously had lived for at least 1 year in temporary housing. At each of the previously mentioned sites in Ishinomaki City, screening was conducted on 2 days each in June, July, and October 2014; on 4 days annually in June and July during 2015 through 2018; and on 2 days in June 2019. Participants were recruited through posters, leaflets, newspapers, and other media. The current study compiled a retrospective cohort of cases that could be followed for at least 3years during the total 6 years of screening. 


\section{Survey details}

The same three respiratory specialists performed the screening exams throughout the 6-year study period. The parameters recorded were a chest radiograph, height, weight, and blood pressure measurements, a collection of $10 \mathrm{~mL}$ of blood, completion of a medical questionnaire written by the authors, and the patient interview. Suspected asthmatic participants underwent auscultation, chest X-ray findings, and respiratory function tests. Airway reversibility tests with inhaled salbutamol were also performed if necessary. Asthma was diagnosed according to the Global Initiative for Asthma (GINA) guidelines. ${ }^{19}$ We described the questionnaire contents, including the extent of the disaster in the patient's immediate environment at the time of the earthquake and the participant's past medical history, in detail in our previous report. ${ }^{10}$

Examinees who underwent multiple annual examinations were divided into four groups according to their asthma patterns: (1) asthma was present at least the first and final examinations (asthma at any screening); (2) asthma was diagnosed at the first examination, but nonasthmatic during the final diagnosis (remission of asthma); (3) nonasthmatic at the first examination but asthmatic at the final evaluation (asthma developed during the study period); and (4) nonasthmatic at the first and final examinations, but asthmatic at an interim time point. We further classified three groups: asthma at the final examination (previous groups 1 and 3), nonasthma at the final examination (previous groups $2+4$ ), and participants free from asthma at all screening examinations.

This study was approved by the ethics committee of the University Hospital Medical Information Network (UMIN ID: UMIN000014376). The hospital ethics committee approved this study in accordance following the Helsinki Declaration. We obtained written informed consent from each patient every year.

\section{Assays \\ Spirometry and airway reversibility}

Asthma was diagnosed in the study participants by the lung function examination and airway reversibility confirmation. The tidal breathing was calculated by using an electric spirometer (Autospiro AS-302, Minato, Osaka, Japan) and nebulizer (model 646, DeVilbiss, Somerset, PA). ${ }^{11}$ According to GINA guidelines, ${ }^{19}$ when forced expiratory volume in 1 second $\left(\mathrm{FEV}_{1}\right)$ increased above $200 \mathrm{~mL}$ or more confirmed reversibility.

\section{IgE antibody levels}

Antigen-specific IgE levels was measured in two mite allergens:-(1) Dermatophagoides farinae (Der $f$ ) and Dermatophagoides pteronyssinus (Der $p$ ). to (2) A. fumigatus by using a combined immunoassay (IMMULITE 3gAllergy, Siemens Healthcare Diagnostics, Tokyo, Japan). ${ }^{20}$ The detection of specific IgE is expressed in terms of quantitative units $\left(\mathrm{IU}_{\mathrm{A}} / \mathrm{mL}\right)$; this commercial assay has a working range of 0.1 to $100 \mathrm{IU}_{\mathrm{A}} / \mathrm{mL}$. Results are considered positive when readings obtained are $\geq 0.35 \mathrm{IU} / \mathrm{mL}$ (score 1 or higher) or $0.1 \mathrm{IU}_{\mathrm{A}} / \mathrm{mL}$ (score 0 , weakly positive).

\section{Measurement of Dermatophagoides group 1 (Der 1) level on futon or mattress}

Bedroom dust samples were collected on adhesive tape and were placed into a polystyrene tube $(10 \times 70 \mathrm{~mm})$. Later they were treated with $2 \mathrm{~mL}$ of phosphate buffer saline (PBS) containing 0.2\% (v/v) Tween 20,0.2\% (w/v) bovine serum albumin (BSA), and $0.05 \%(\mathrm{w} / \mathrm{v})$ sodium azide (PBS-T-BSA) by placing them on an orbital shaker overnight at room temperature. Samples on adhesive tape at 1:100 $\mathrm{w} / \mathrm{v}(20 \mathrm{mg}$ in $2 \mathrm{~mL}$ ) PBS-T-BSA were then extracted for $4 \mathrm{~h}$ at room temperature. A previously developed fluorometric enzyme-linked immunosorbent assay was used to quantify $\operatorname{Der} p 1$ or $\operatorname{Der} f 1 .{ }^{21,22}$ Results were expressed as nanograms of allergen $/ \mathrm{m}^{2}$ on adhesive tape as reported by a previous method..$^{23}$ Intersample variation was accounted for by averaging the results from two adhesive tape samples.

\section{Allergen avoidance strategy}

In March 2017, 18 random participants who were living currently or had lived previously in temporary housing were provided with microfiber covers (Microgard, Yasaka Co., Tokyo, Japan) for their pillows and futons or mattresses, along with instructions regarding a checklist for allergen avoidance included 32 techniques in five sections: humidity countermeasures, control of sources of Der-1 pollution, overall management of bedding, maintenance of futons or beds, and efficient cleaning of bedrooms. ${ }^{24}$ The Der 1 level on the futon or mattress was measured by sampling the bedding for mites before, immediately after, and at two weeks post the microfiber cloth covers application and allergen avoidance guidance received. The mite allergen avoidance according to the 32 -item checklist ${ }^{24}$ was readdressed, and the participant's test outcomes for that year were provided in an annual environment improvement seminar.

\section{Statistical analysis}

All values are expressed as mean \pm standard deviation (SD) or median \pm standard mean error unless otherwise specified. Data from two groups were compared statistically by using the Mann-Whitney U-test. Group comparison by using two-way analysis of variance with repeated measures or with chi-squared testing revealed no significant differences. Mean values for data obtained at seasonal time points, before and after the intervention, or at first and final examinations were compared using the Wilcoxon matched-pairs t-test. The area under the curve and the 95\% confidence interval $(\mathrm{Cl})$ were also determined. $P$ values less than 0.05 were considered statistically significant. All statistical analyses were performed using SPSS for Windows, version 20 (SPSS, Chicago, IL). 


\section{Results}

We recruited 202 examinees whose clinical course was followed for at least 3 years during the 6-year examination period. Overall, $41.6 \%$ of the participants were men, and the average age at the first examination was $63.0 \pm 13.9$ years. During the final examination, $79.2 \%$ of study participants were no longer in temporary housing after having lived there for $4.4 \pm 1.4$ years, and the period of moving out of temporary housing $5.9 \pm 7.7$ years (Table 1 ). Of the 202 participants, 72 (35.6\%) were asthmatic at least once during the examination. In this subgroup, asthma onset occurred in 17 (23.6\%) before the earthquake, three (4.2\%) during their stay in shelters , 44 (61.1\%) after moving into temporary housing, and eight (11.1\%) after moving out of temporary housing . More than half, 38 (52.8\%) of these asthma cases were mild in severity, and many of these participants were in the normal range of lung function for both \%FEV 1 and \% peak expiratory flow rate at $50 \%$ of forced vital capacity (V50). Positive ratios of antigen-specific IgE in serum for Der $p$ (both $\geq 0.35$ and $\geq 0.10$ $\mathrm{IU}_{\mathrm{A}} / \mathrm{mL}$ ) were more than four times those for $A$. fumigatus (Table 1).

Participants who were asthmatic at the final screening were younger at study entry than those who were nonasthmatic at the final $(P<0.05)$ or at all screenings $(P<$ 0.01). During the entry and exit of temporary housing, no difference in smoking history was noticed among asthmatic or nonasthmatic at the final examination or nonasthma at all screening (Table 2). The history of allergic disease did not differ among the three patient subgroups. But a family history of asthma was more prevalent among those who were asthmatic at the final screening compared with nonasthmatic at all screenings $(P<0.01)$, and a family history of allergic rhinitis was more in asthma present at the final screening than those in nonasthma at the final screening $(P$ $<0.05)$. The asthma onset pattern did not differ between asthmatic and nonasthmatic at the final examination. The age of onset of asthma at a younger and disease severity was greater for asthmatic participants versus nonasthmatic at the final examination. Lung function assessed as $\% \mathrm{FEV}_{1}$ and \%V50 did not differ among the three patient subgroups. Positive ratio of antigen-specific serum IgE (both $\geq 0.35$ and $\geq 0.10 \mathrm{IU}_{\mathrm{A}} / \mathrm{mL}$ ) for Der $p$ was higher in participants who were asthmatic compared with nonasthmatic at the last examination $(\mathrm{P}<0.01,<0.05)$ or nonasthmatic at all screenings $(P<0.01)$. However, the positive ratio of A. fumigatus-specific serum IgE did not differ among the three subgroups (Table 2).

Figure 1 shows that the Der 1 level on futons or mattresses did not differ among temporary housing, new detached houses, and reconstruction housing between autumn (i.e., October) and winter (i.e., January). However, the Der 1 level on futons or mattresses increased from summer (i.e., June or July) to autumn $(P<0.01)$ in new detached houses and reconstruction housing but did not vary in temporary housing (Figure 2).

The Der 1 level on futons or mattresses did not change between the first and final examination for asthmatic at the final screening or nonasthmatic during the study period. A significant decrease was noticed between examinations for nonasthmatic at the final screening $(P<0.01$; Figure 3$)$.
Table 1 Characteristics of the 202 study participants, who had a history of living in temporary housing and at least a three-year follow-up period.

\section{Characteristic}

Age at study entry (years; mean \pm SD)

Sex (male/female, $n$ )

$63.0 \pm 13.9$

Living temporary housing at last $84 / 118$ examination $(\mathrm{n})$

Out of temporary housing at last examination $(\mathrm{n})$

Housing at the time of the final examination(temporary housing/ new detached house/reconstruction house/rental housing)

Period of stay in temporary housing (years; mean $\pm \mathrm{SD}$ )

Period out of temporary housing (years; mean $\pm \mathrm{SD}$ )

Smoking history (never/ex-smoker/ current smoker)

$42(20.8 \%)$

$160(79.2 \%)$

$42 / 52 / 104 / 4$

History of allergic disease

Childhood onset of asthma (n)

Allergic rhinitis (yes/no)

Atopic dermatitis (yes/no)

9/193 (4.5\%)

$57 / 145(28.2 \%)$

$16 / 186(7.9 \%)$

Family history of asthma (yes/no)

27/175 (13.4\%)

Family history of allergic rhinitis

$45 / 157(22.3 \%)$ (yes/no)

Family history of atopic dermatitis (yes/no)

$22 / 180(10.9 \%)$

Presence of asthma according to doctor's diagnosis (yes/no)

$72 / 130(35.6 \%)$

Onset of asthma $(n=72)$

Before the Great East Japan

Earthquake (n)

At shelter $(\mathrm{n})$

17 (23.6\%)

After moving

$3(4.2 \%)$

housing $(\mathrm{n})$

After moving out of temporary

housing (n)

Severity of asthma ${ }^{a}($ Step $1 / 2 / 3 / 4)$

$8(11.1 \%)$

$38 / 17 / 14 / 3$

Lung function test at first screening $(n=119)$ $\mathrm{FEV}_{1}$ (predicted \%) (mean $\left.\pm \mathrm{SD}\right) \quad 96.3 \pm 17.6$ $\mathrm{V}_{50}$ (predicted \%) (mean $\left.\pm \mathrm{SD}\right) \quad 89.1 \pm 36.5$

Antigen-specific lgE level in serum $\left(\geq 0.35 \mathrm{IU}_{\mathrm{A}} / \mathrm{mL}\right)$ at first screening

Dermatophagoides farinae (yes/no)

$45 / 157(22.3 \%)$ Aspergillus fumigatus (yes/no) $10 / 192(5 \%)$

Antigen-specific lgE level in serum $(\geq 0.10 \mathrm{IU} / \mathrm{mL})$ at first screening

D. farinae (yes/no)

$75 / 127(37.1 \%)$

A. fumigatus (yes/no)

$16 / 186(7.9 \%)$

${ }^{a}$ According to GINA ${ }^{19}$ guideline.

$\mathrm{SD}$, standard deviation; FEV1, forced expiratory volume in 1 second; V50, peak expiratory flow rate at $50 \%$ of forced vital capacity. 
Table 2 Background factors according to clinical course.

\begin{tabular}{|c|c|c|c|c|}
\hline & $\begin{array}{l}\text { Asthma present } \\
\text { at final screening }\end{array}$ & $\begin{array}{l}\text { Nonasthmatic at the } \\
\text { final examination }\end{array}$ & $\begin{array}{l}\text { Nonasthmatic at } \\
\text { all screenings }\end{array}$ & $\mathrm{P}$ \\
\hline \multicolumn{5}{|l|}{ Clinical course } \\
\hline $\begin{array}{l}\text { Asthma present at any screening/Asthma } \\
\text { developed during screening period. }\end{array}$ & $30 / 15$ & & & \\
\hline $\begin{array}{l}\text { Asthma present at the first screening } \\
\text { but nonasthmatic at the final } \\
\text { screening/asthma developed during } \\
\text { the examination period but was } \\
\text { diagnosed as nonasthmatic at the final } \\
\text { examination. }\end{array}$ & & $13 / 14$ & & \\
\hline Age at study entry (years) & $60.2 \pm 15.2$ & $67.7 \pm 10.2$ & $69.4 \pm 12.7$ & $<0.05^{*},<0.01^{* *}, \mathrm{NS}^{* * *}$ \\
\hline Sex (male/female, $\mathrm{n}$ ) & $17 / 28$ & $10 / 17$ & $57 / 73$ & $N S^{*},{ }^{* *}, * * *$ \\
\hline $\begin{array}{l}\text { Living in temporary housing at last } \\
\text { examination }(\mathrm{n})\end{array}$ & $7(15.6 \%)$ & $5(18.5 \%)$ & $30(23.1 \%)$ & NS \\
\hline $\begin{array}{l}\text { Out of temporary housing at last } \\
\text { examination }(\mathrm{n})\end{array}$ & $38(84.4 \%)$ & $22(81.5 \%)$ & $100(76.9 \%)$ & \\
\hline $\begin{array}{l}\text { Housing at the time of the final } \\
\text { examination (temporary housing/new } \\
\text { detached house/reconstructed house/ } \\
\text { rental housing) }\end{array}$ & $7 / 7 / 29 / 2$ & $5 / 4 / 18 / 0$ & $30 / 41 / 57 / 2$ & NS \\
\hline $\begin{array}{l}\text { Time in temporary housing } \\
\text { (years; mean } \pm \text { SD) }\end{array}$ & $3.9 \pm 1.3$ & $4.4 \pm 1.1$ & $4.5 \pm 1.5$ & $N S^{*},{ }^{* *}, * * *$ \\
\hline $\begin{array}{l}\text { Period out of temporary housing } \\
\quad \text { (years; mean } \pm \text { SD) }\end{array}$ & $3.9 \pm 1.3$ & $7.1 \pm 8.2$ & $6.1 \pm 8.2$ & $\mathrm{NS}^{*},{ }^{* *},{ }^{* * *}$ \\
\hline $\begin{array}{l}\text { Smoking history (never/exsmoker/current } \\
\text { smoker) }\end{array}$ & $25 / 16 / 4$ & $17 / 7 / 3$ & $62 / 40 / 28$ & NS \\
\hline \multicolumn{5}{|l|}{ History of allergic disease } \\
\hline Childhood onset of asthma (n) & $8 / 37(17.8 \%)$ & $1 / 26(3.7 \%)$ & $0 / 130(0 \%)$ & NS \\
\hline Allergic rhinitis (yes/no) & $14 / 31(31.1 \%)$ & $3 / 24(11.1 \%)$ & $30 / 100(23.1 \%)$ & NS \\
\hline Atopic dermatitis (yes/no) & $1 / 44(2.2 \%)$ & $0 / 27(0 \%)$ & $4 / 126(3 / 1)$ & NS \\
\hline Family history of asthma (yes/no) & $15 / 30(33.3 \%)$ & $3 / 24(11.1 \%)$ & $9 / 121(6.9 \%)$ & $<0.01^{* *}, \mathrm{NS}^{*},{ }^{* * *}$ \\
\hline Family history of allergic rhinitis (yes/no) & $10 / 35(22.2 \%)$ & $1 / 26(3.7 \%)$ & $14 / 116(10.8 \%)$ & $<0.05^{*}, \mathrm{NS}^{* *},{ }^{* * *}$ \\
\hline Family history of atopic dermatitis (yes/no) & $6 / 39(13.3 \%)$ & $1 / 26(3.7 \%)$ & $5 / 125(3.8 \%)$ & NS \\
\hline Onset of asthma & & & & NS* \\
\hline $\begin{array}{l}\text { Before the Great East Japan Earthquake } \\
\text { (n) }\end{array}$ & $13(28.9 \%)$ & $4(14.8 \%)$ & & \\
\hline At shelter $(n)$ & $2(4.4 \%)$ & $1(3.7 \%)$ & & \\
\hline After moving into temporary housing (n) & $25(55.6 \%)$ & 19 (70.4\%) & & \\
\hline $\begin{array}{l}\text { After moving out of temporary housing } \\
\text { (n, \%) }\end{array}$ & $5(11.1 \%)$ & $3(11.1 \%)$ & & \\
\hline Age at onset of asthma (years; mean \pm SD) & $49.1 \pm 20.4$ & $58.2 \pm 13.3$ & & $<0.05^{*}$ \\
\hline Severity of asthma (Step 1/2/3/4) & $17 / 13 / 12 / 3$ & $21 / 4 / 2 / 0$ & & $<0.01^{*}$ \\
\hline \multicolumn{5}{|l|}{$\begin{array}{l}\text { Lung function test at first screening } \\
\qquad(\mathrm{n}=119)\end{array}$} \\
\hline $\mathrm{FEV}_{1}($ predicted $\%)($ mean \pm SD) & $93.8 \pm 16.6$ & $98.4 \pm 20.5$ & $97.2 \pm 17.1$ & $\mathrm{NS}^{*},{ }^{* *},{ }^{* * *}$ \\
\hline $\mathrm{V}_{50}($ predicted $\%)($ mean $\pm \mathrm{SD})$ & $82.4 \pm 38.1$ & $89.2 \pm 28.8$ & $93.9 \pm 38.3$ & $N S^{*},{ }^{* *},{ }^{* * *}$ \\
\hline \multicolumn{5}{|l|}{$\begin{array}{l}\text { Antigen-specific lgE level in serum } \\
\left(\geq 0.35 \mathrm{IU}_{\mathrm{A}} / \mathrm{mL}\right) \text { at first screening }\end{array}$} \\
\hline Dermatophagoides farinae (yes/no) & $18 / 27(40 \%)$ & $2 / 25(7.4 \%)$ & $25 / 105$ (19.2\%) & $<0.01^{*},{ }^{* *}, \mathrm{NS}^{* * *}$ \\
\hline Aspergillus fumigatus (yes/no) & $4 / 41(8.9 \%)$ & $1 / 25(3.8 \%)$ & $5 / 124(3.9 \%)$ & $\mathrm{NS}^{*},{ }^{* *}, * * *$ \\
\hline \multicolumn{5}{|l|}{$\begin{array}{l}\text { Antigen-specific lgE level in serum } \\
\left(\geq 0.10 \mathrm{IU} \mathrm{U}_{\mathrm{A}} / \mathrm{mL}\right) \text { at first screening }\end{array}$} \\
\hline D. farinae (yes/no) & $26 / 19(57.8 \%)$ & $8 / 19(29.6 \%)$ & $41 / 89$ (31.5) & $<0.05^{*},<0.01^{* *}, \mathrm{NS}^{* * *}$ \\
\hline A. fumigatus (yes/no) & $26 / 19(57.8 \%)$ & $2 / 24(7.7 \%)$ & $10 / 119(7.8 \%)$ & NS $*, * *, * * *$ \\
\hline
\end{tabular}

*Presence of asthma at the final examination versus nonasthmatic at the final examination.

**Asthma present at the final examination versus nonasthmatic at all screening.

*** Nonasthmatic at the final examination versus nonasthmatic at all screening.

SD, standard deviation. 


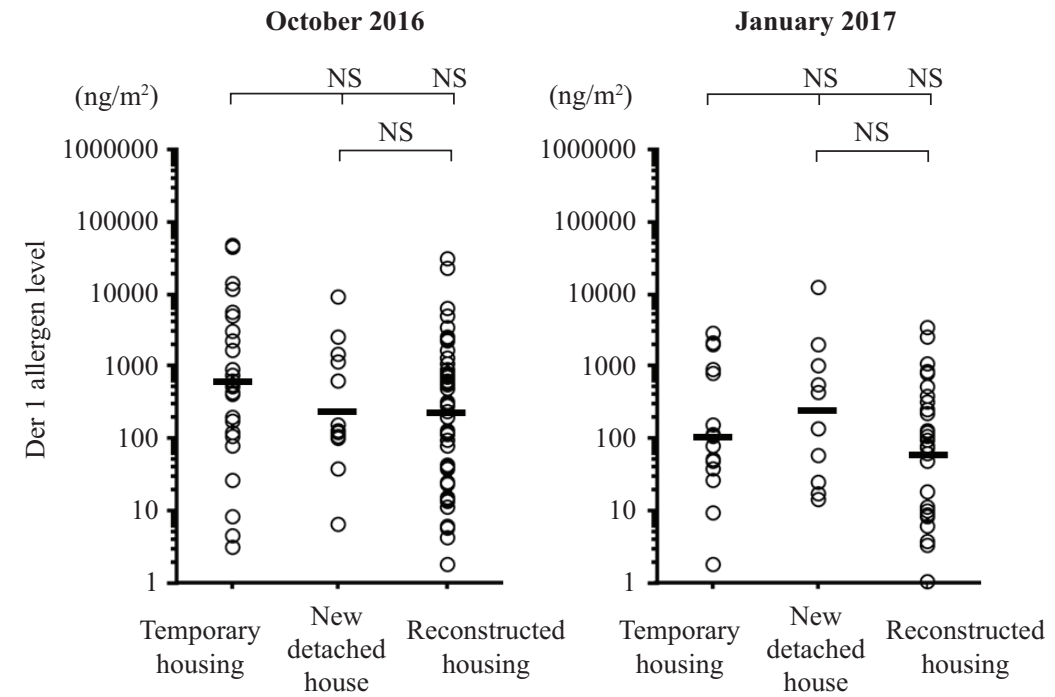

Figure 1 Der 1 level on futons or mattresses according to residence type (temporary housing, new construction, and reconstructed housing) between October 2016 and January 2017.

Temporary housing

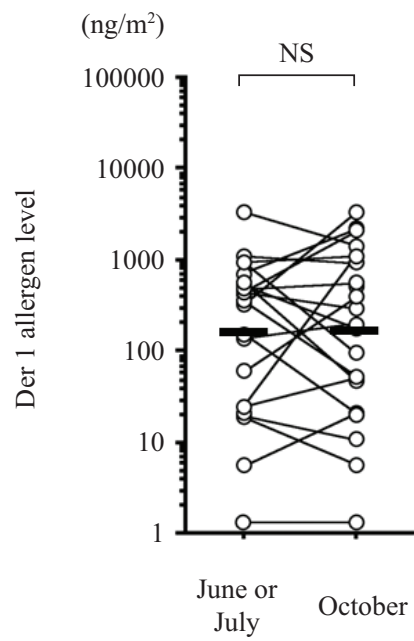

New detached house

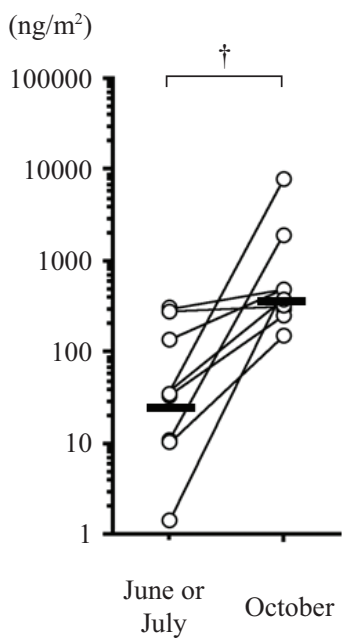

Reconstructed housing

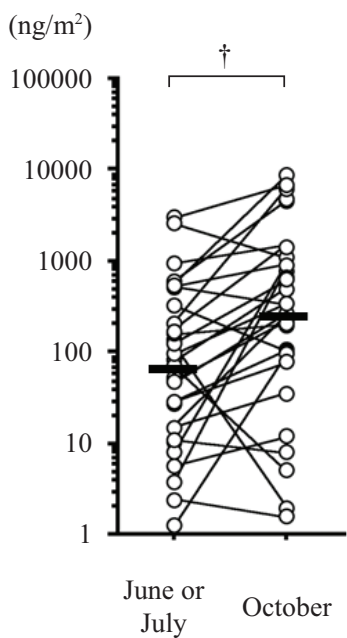

Figure 2 Der 1 level on futons or mattresses according to residence type (temporary housing, new construction, and reconstructed housing) from June or July 2017 to October 2017.

Serum levels of Der $f$ specific IgE remained consistent between the first and final examinations in nonasthmatic during the study period. A significant increase $(P<0.05)$ from first to the final examination for the asthmatic and a decrease in nonasthmatic at the final screening was recorded $\mathrm{P}<0.01$; Figure 4).

\section{Discussion}

In two previous studies, the Der 1 level on the mattresses or futons of adult patients with asthma were 44. and 45.0 $\mathrm{ng} / \mathrm{m}^{2}$ on average during the autumn. ${ }^{24,25}$ In contrast, in the current study, the mean Der 1 level on the mattresses or futons of adults with asthma who lived in temporary housing, new constructions, or reconstructed housing in
Ishinomaki City after the Great East Japan earthquake exceeded $200 \mathrm{ng} / \mathrm{m}^{2}$.

Der 1 allergen levels on mattresses or futons tend to increase in the autumn and decrease in the winter. ${ }^{26,27}$ Ishinomaki City is in the Tohoku region of Japan, and the climate in early summer is relatively dry, with little rain. Our current results show that, although the Der 1 allergen level on mattresses or futons in newly constructed and reconstructed housing increased from early summer to autumn, Der 1 level in temporary housing showed scant to no seasonal variation.

To motivate participants to minimize their allergen exposure, we reported the Der 1 allergen levels on mattresses or futons and the screening results, such as the prevalence of asthma, to the study participants every year. In addition to microfiber covers and acaricides use, cleaning methods like vacuuming the mattress surfaces, washing 
(a)

Asthma present at final screening

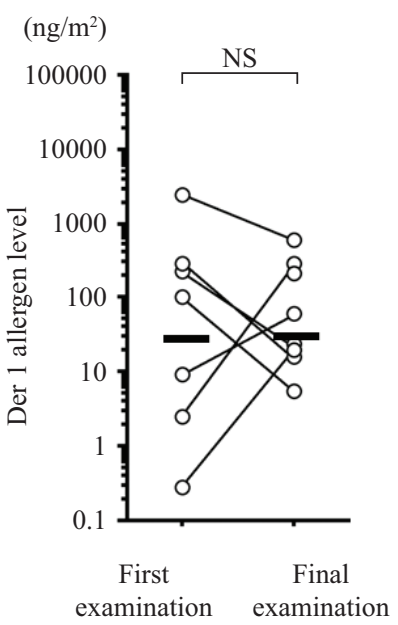

(b)

Non-asthmatic at final screening

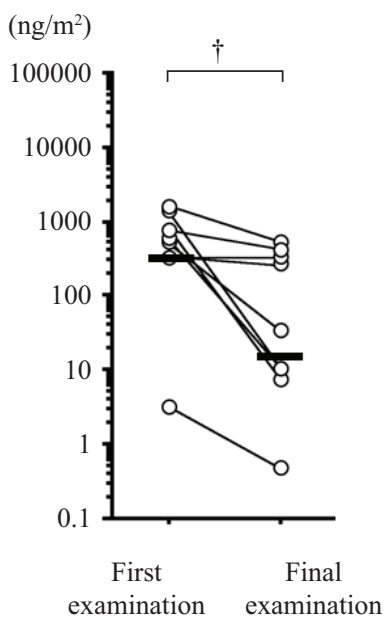

(c)

Non-asthma at all screenings

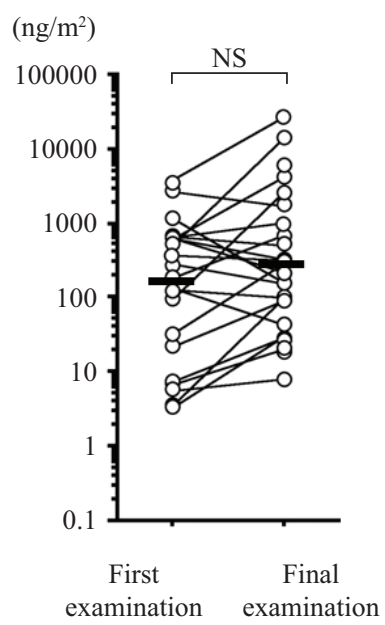

Figure 3 Der 1 level on futons or mattresses in the study period in asthmatic participants at the final screening, $\mathrm{N}=7$ (a), nonasthmatic at the final screening, $\mathrm{N}=9$ (b), and nonasthmatic at all screenings, $\mathrm{N}=23$ (c).

(a)

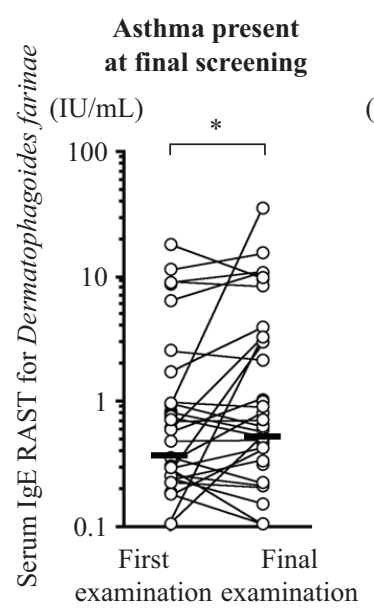

(b)
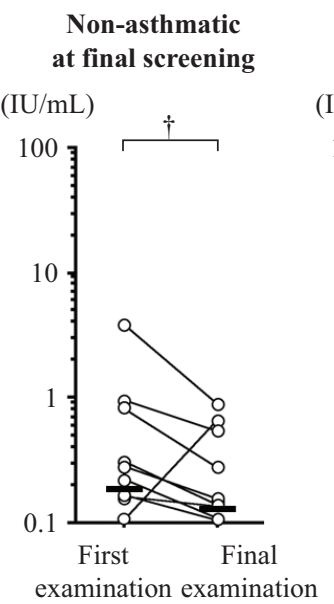

(c)

$$
\begin{aligned}
& \text { Non-asthma } \\
& \text { at all screenings }
\end{aligned}
$$

$(\mathrm{IU} / \mathrm{mL})$

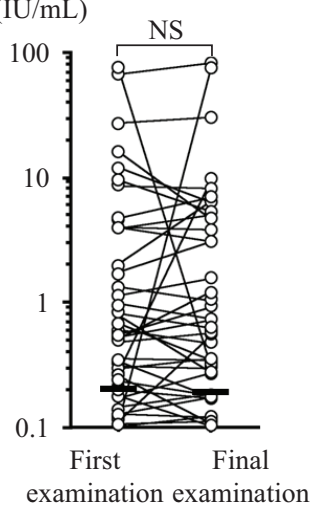

Figure 4 Serum level of Dermatophagoides farina specific IgE during the study period in participants who were asthmatic at the final screening, $\mathrm{N}=45$ (a), nonasthmatic at the final screening, $\mathrm{N}=27$ (b), and nonasthmatic at all screenings, $N=130$ (c).

sheets with hot water $\left(60^{\circ} \mathrm{C}\right.$ or higher $)$, and removing carpets and stuffed toys decrease allergen levels. ${ }^{28-32}$ Whether any particular method or combination of techniques is optimal is unknown. ${ }^{33}$ We have demonstrated that vacuuming the surfaces of mattresses, exposing the futons to sunlight, and wiping the floor before vacuuming are all useful in reducing mite allergens as a part of the 32-task checklist. ${ }^{24}$ Besides, although a particular maintenance method might be ineffective regarding allergen avoidance on its own, its inclusion with other techniques may effectively curtail allergen exposure. ${ }^{34}$

Serum Der $f$-specific IgE levels were increased in asthmatic participants but decreased in nonasthmatic at the final examination. We attribute the abatement of asthma symptoms in these participants to the decreased Der 1 level on their futons or mattresses and the decreased serum Der $f$-specific IgE levels.

Many strategies to enhance antigen avoidance for adult asthma are ineffective. ${ }^{28,29}$ For example, a meta-analysis of seven primary prevention trials and 17 tertiary prevention trials failed to yield any evidence to support the impermeable mattress use for alleviating allergic disease symptoms. ${ }^{29}$ The reduction of mite allergen levels on mattresses was effective for tertiary prevention of asthma symptoms and promotion of lung function, which some studies found ineffective, so no conclusion could be reached. ${ }^{28}$ Another study suggested that the use of mattresses and pillow covers of microfiber and acaricides reduced the mite allergen levels in the bedroom and ameliorated airway hyperresponsiveness 
in adult asthma with near-normal lung function and mild airway hyperresponsiveness. ${ }^{30}$ Conversely, reducing mite antigen exposure had no significant effect on moderate or mild asthma in another study. ${ }^{31}$ Hence, no definitive conclusion could be reached regarding the effectiveness of minimizing antigen exposure. So, the GINA guidelines do not recommend antigen avoidance as a treatment strategy for asthma. ${ }^{19}$

More than half of the cases of asthma that we identified during screening examinations were categorized as GINA Step 1- mild intermittent asthma. Several of the reports regarding antigen avoidance for adult asthma are analyzed according to the number and nature of cases; few studies have collected and studied only mild cases of asthma. ${ }^{30}$ Given the considerable proportion of mild asthma among our examinees, we consider that the avoidance of mite allergens would be a beneficial therapeutic strategy that avoids the use of inhaled corticosteroids in adults with mild asthma.

This study has several limitations. First, only 12 residents were evaluated during the entire study period of 6 years. Besides, we analyzed data from only those participants with a follow-up of at least 3 years; consequently, the number of cases was small. Second, the range of the Der 1 level on futons and mattresses varied widely. Third, the number of residents moving out of temporary housing had increased since 2016, making it difficult to secure candidates for medical examinations.

Finally, the number of dust mites in bedding can be affected by environmental maintenance instructions. In this study, the checklist were provided to all 18 patients. Of the study participants, only one nonasthmatic patient at the final examination received environmental guidance, and it is unlikely to affect the study conclusion.

\section{Conclusion}

The current study shows that allergen avoidance measures can help to limit asthma symptoms even after adult atopic asthma develops following exposure to mite allergens because of changes in the living environment. Environmental maintenance can be effective in situations where mites are contaminating the environment.

\section{Author's contributions}

N. Tsurikisawa analyzed participants' data and takes responsibility for the overall article presentation. $\mathrm{N}$. Tsurikisawa, M.o Watanabe, and M. Yanai people negotiated with the administration in conducting the medical examination. C. Oshikata, M. Ishida, N. Tsurikisawa diagnosed asthma residents. C. Oshikata analyzed participant's data and wrote the first draft. N. Tsurikisawa, C. Oshikata, M. Watanabe, S. Kobayashi, M. Yanai, Y. Kamata, T. Kaneko, and S. Kuriyama conceived the study idea and participated in the discussion. K. Hashimoto, N. Kobayashi, R. Konuma, and $\mathrm{A}$. Yamazaki helped with height and weight measurements, blood pressure measurements, interviews, and lung function measurements. T. Shimada measured Der 1 level on futon or mattress.

\section{Acknowledgments}

The authors thank Ms. Yumiko Takeuchi and Ms. Masayo Morie for performing the pulmonary function tests, Ms. Yuka Taira for blood sampling, and Ms. Takako Oi for being the examination assistant.

\section{Conflict of interest}

No potential conflict of interest was reported by the authors.

\section{Funding}

This study was funded by a Health and Labor Sciences Research Grant (Research on Health Security Control, H24Kenki-wakate-001), and the International Research Institute of Disaster Science (IRIDeS) coproject 2016.

\section{References}

1. Carlos WG, Cruz CD, Jamil S, Kipen H, Rose C. Mold-specific concerns associated with water damage for those with allergies, asthma, and other lung diseases. Am J Respir Crit Care Med. 2017;196:13-14. https://doi.org/10.1164/rccm.1967P13

2. Johanning E, Auger P, Morey PR, Yang CS, Olmsted E. Review of health hazards and prevention measures for response and recovery workers and volunteers after natural disasters, flooding, and water damage: Mold and dampness. Environ Health Prev Med. 2014;19:93-9. https://doi.org/10.1007/ s12199-013-0368-0

3. Jaakkola MS, Nordman H, Piipari R, Uitti J, Laitinen J, Karjalainen A, et al. Indoor dampness and molds and development of adult-onset asthma: A population-based incident case-control study. Environ Health Perspect. 2002;110:543-7. https://doi.org/10.1289/ehp.02110543

4. Mendell MJ, Mirer AG, Cheung K, Tong M, Douwes J. Respiratory and allergic health effects of dampness, mold, and dampness-related agents: a review of the epidemiologic evidence. Environ Health Perspect. 2011;119:748-56. https:// doi.org/10.1289/ehp.1002410

5. Park JH, Cox-Ganser JM, Kreiss K, White SK, Rao CY. Hydrophilic fungi and ergosterol associated with respiratory illness in a water-damaged building. Environ Health Perspect. 2008;116:45-50. https://doi.org/10.1289/ehp.10355

6. Ishikuro M, Matsubara H, Kikuya M, Obara T, Sato Y, Metoki H, et al. Disease prevalence among nursery school children after the Great East Japan earthquake. BMJ Glob Health. 2017;2:e000127. https://doi.org/10.1136/bmjgh-2016-000127

7. Miyashita M, Kikuya M, Yamanaka C, Ishikuro M, Obara T, Sato Y, et al. Eczema and asthma symptoms among schoolchildren in coastal and inland areas after the 2011 Great East Japan Earthquake: The ToMMo child health study. Tohoku J Exp Med. 2015;237:297-305. https://doi.org/10.1620/tjem.237.297

8. Ohkouchi S, Shibuya R, Yanai M, Kikuchi Y, Ichinose M, Nukiwa T. Deterioration in regional health status after the acute phase of a great disaster: respiratory physicians' experiences of the Great East Japan Earthquake. Respir Investig. 2013;51:50-5. https://doi.org/10.1016/j.resinv.2012.12.003

9. Yamanda S, Hanagama M, Kobayashi S, Satou H, Tokuda S, Niu K, et al. The impact of the 2011 Great East Japan Earthquake on hospitalisation for respiratory disease in a rapidly aging society: A retrospective descriptive and cross-sectional study at the disaster base 
hospital in Ishinomaki. BMJ Open. 2013;3:pii:e000865. https:// doi.org/10.1136/bmjopen-2012-000865

10. Oshikata C, Watanabe $M$, Ishida M, Kobayashi S, Hashimoto K, Kobayashi $\mathrm{N}$, et al. Increase in asthma prevalence in adults in temporary housing after the Great East Japan Earthquake. Int J Disaster Risk Reduct. 2020;50:101696. https://doi. org/10.1016/j.ijdrr.2020.101696

11. Furukawa K, Arai H. Earthquake in Japan. Lancet. 2011;377 (9778):1652. https://doi.org/10.1016/S0140-6736(11)60671-5

12. Kaufhold T, Fiedler K, Jung G, Lindner M, Gassel RP. Moisture and mold on the inner walls of prefabricated building slabsinvestigating a strange cause. Zentralbl Hyg Umweltmed. 1997;199:527-36.

13. Parthasarathy S, Maddalena RL, Russell ML, Apte MG. Effect of temperature and humidity on formaldehyde emissions in temporary housing units. J Air Waste Manag Assoc. 2011;61:68995. https://doi.org/10.3155/1047-3289.61.6.689

14. Gangneux JP, Bouvrais M, Frain S, Morel H, Deguen S, Chevrier S. Asthma and indoor environment: Usefulness of a global allergen avoidance method on asthma control and exposure to molds. Mycopathologia. 2020;185:367-71. https://doi. org/10.1007/s11046-019-00417-9.

15. Naegele A, Reboux G, Scherer E, Roussel S, Millon L. Fungal food choices of Dermatophagoides farinae affect indoor fungi selection and dispersal. Int J Environ Health Res. 2013;23:915. https://doi.org/10.1080/09603123.2012.699029

16. Shinohara N, Tokumura M, Hashimoto K, Asano K, Kawakami Y. Fungal levels in houses in the Fukushima Daiichi nuclear power plant evacuation zone after the Great East Japan Earthquake. J Air Waste Manag Assoc. 2017;67:1106-14. https://doi.org/10.1 080/10962247.2017.1330712

17. Fukutomi $Y$, Nakamura $H$, Kobayashi F, Taniguchi M, Konno S, Nishimura $M$, et al. Nationwide cross-sectional population-based study on the prevalences of asthma and asthma symptoms among Japanese adults. Int Arch Allergy Immunol. 2010;153:280-7. https://doi.org/10.1159/000314369

18. Fukutomi $\mathrm{Y}$, Taniguchi $\mathrm{M}$, Watanabe J, Nakamura $\mathrm{H}$, Komase $\mathrm{Y}$, Ohta $\mathrm{K}$, et al. Time trend in the prevalence of adult asthma in Japan: Findings from population-based surveys in Fujieda City in 1985, 1999, and 2006. Allergol Int. 2011;60:443-8. https:// doi.org/10.2332/allergolint.10-OA-0282

19. Global Initiative for Asthma (GINA). Interim guidance about COVID-19 \& asthma. [Internet]. [Updated on 30 March 2021]. Available from: http://www.ginasthma.org/.

20. Watanabe M, Hirata H, Arima M, Hayashi Y, Chibana K, Yoshida N, et al. Measurement of hymenoptera venom specific IgE by the IMMULITE $3 \mathrm{~g}$ allergy in subjects with negative or positive results by ImmunoCAP. Asia Pac Allergy. 2012;2:195-202. https://doi.org/10.5415/apallergy.2012.2.3.195

21. Tovey ER, Marks GB, Matthews M, Green WF, Woolcock A. Changes in mite allergen Der $p I$ in house dust following a spraying with a tannic acid/acaricide solution. Clin Exp Allergy. 1992;22:67-74. https://doi.org/10.1111/j.1365-2222.1992.tb00116.x

22. Yasueda H, Saito A, Akiyama K, Maeda Y, Shida M, Sakaguchi M, et al. Estimation of $\operatorname{Der} p$ and $\operatorname{Der} f 1$ quantities in the reference preparations of Dermatophagoides mite extracts. Clin Exp Allergy. 1994;19:1030-5. https://doi.org/10.1111/j.1365-2222.1994. tb02739.x

23. Tovey ER, Mitakakis TZ, Sercombe JK, Vanlaar CH, Marks GB. Four methods of sampling for dust mite allergen: Differences in "dust". Allergy. 2003;58:790-4. https://doi. org/10.1034/j.1398-9995.2003.00228.x

24. Tsurikisawa N, Saito A, Oshikata C, Yasueda H, Akiyama K. Effective allergen avoidance for reducing exposure to house dust mite allergens and improving disease management in adult atopic asthmatics. J Asthma. 2016;8:843-53. https://doi. org/10.3109/02770903.2016.1155218

25. Tsurikisawa N, Saito A, Oshikata C, Nakazawa T, Yasueda H, Akiyama $\mathrm{K}$. Encasing bedding in covers made of microfine fibers reduces exposure to house mite allergens and improves disease management in adult atopic asthmatics. Allergy Asthma Clin Immunol. 2013;9:44-53. https://doi. org/10.1186/1710-1492-9-44

26. Miyazawa H, Sakaguchi M, Inouye S, Ikeda K, Honbo Y, Yasueda H, et al. Seasonal changes in mite allergen (Der I and Der II) concentrations in Japanese homes. Ann Allergy Asthma Immunol. 1996;76:170-4. https://doi.org/10.1016/S1081-1206(10)63418-7

27. Saito A, Tsurikisawa N, Oshikata C, Nakazawa T, Yasueda H, Akiyama K. Evaluation of Petri dish sampling for assessment of airborne dust mite allergen in Japan. Arerugi. 2012;61:1657-64.

28. van Boven FE. Effectiveness of mite-impermeable covers: A hypothesis-generating meta-analysis. Clin Exp Allergy. 2014;44:1473-83. https://doi.org/10.1111/cea.12376

29. Arroyave WD, Rabito FA, Carlson JC, Friedman EE, Stinebaugh SJ. Impermeable dust mite covers in the primary and tertiary prevention of allergic disease: A meta-analysis. Ann Allergy Asthma Immunol. 2014;112 :237-48. https://doi.org/10.1016/j. anai.2014.01.006

30. Heide S, Kauffman HF, Dubois AE, Monchy JG. Allergenavoidance measures in homes of house-dust-mite-allergic asthmatic patients: Effects of acaricides and mattress encasings. Allergy. 1997;52:921-7. https://doi.org/10.1111/j.1398-9995.1997. tb01252.x

31. van Boven FE, de Jong NW, Braunstahl GJ, Gerth van Wijk R, Arends LR. A meta-analysis of baseline characteristics in trials on mite allergen avoidance in asthmatics: Room for improvement. Clin Transl Allergy. 2020;10:2. https://doi.org/10.1186/ s13601-019-0306-3.E

32. Wilson JM, Platts-Mills TAE. Home environmental interventions for house dust mite. J Allergy Clin Immunol Pract. 2018;6:1-7. https://doi.org/10.1016/j.jaip.2017.10.003

33. van Boven FE, Arends LR, Braunstahl GJ, van Wijk RG. A reintroduction of environmental mite allergen control strategies for asthma treatment and the debate on their effectiveness. Clin Exp Allergy. 2019;49:400-9. https://doi.org/10.1111/cea.13340

34. Leas BF, D’Anci KE, Apter AJ, Bryant-Stephens T, Lynch MP, Kaczmarek JL, et al. Effectiveness of indoor allergen reduction in asthma management: A systematic review. J Allergy Clin Immunol. 2018;141:1854-69. https://doi.org/10.1016/j. jaci.2018.02.001 